\title{
FEE ARRANGEMENTS AND FEE SHIFTING: LESSONS FROM THE EXPERIENCE IN ONTARIO
}

\author{
HERBERT M. KRITZER*
}

I

\section{INTRODUCTION}

The research discussed below was not originated with the intention of examining the impact of fee shifting; rather, the research was planned as a small-scale follow up to some of the work I did with the Civil Litigation Research Project (CLRP). ${ }^{1}$ One of the interesting things that emerged from my work on CLRP was the significant changes that are occurring in the ways that large corporations purchase legal services. Specifically, corporations are trying to rationalize, in a business sense, the way they use lawyers. ${ }^{2}$ These efforts are apparent in two separate movements: the shift toward greater reliance upon inside legal staffs, and the increase in the level of monitoring and control that corporations seek to exercise over outside legal counsel. These observations, which arose primarily from informal contacts with corporations during the researching rather than from the formal interviews that were conducted, led to speculation that the movement toward greater control, which primarily reflected a concern about costs, was in large part due to the lack of any kind of formal controls in the United States on what lawyers charge for their services. I speculated that in a system in which there were formal cost-control or cost-review mechanisms, there might be substantially less concern about legal costs, and as a result, less movement toward the use of inside lawyers or toward close monitoring of outside law firms.

The logical place to conduct a comparative inquiry of the type suggested by my hypothesis was either England or Canada, since both countries (excluding the

Copyright (C) 1984 by Law and Contemporary Problems

* Department of Political Science, University of Wisconsin-Madison. This work was supported by the Research Committee of the University of Wisconsin-Madison Graduate School. I would like to thank Judge James Felstiner for his assistance at a crucial stage of the research. I would also like to thank the Center for Criminology, University of Toronto, for making its facilities available to me during my time in Toronto, and Garry Watson, for providing extremely valuable comments on an earlier draft of the paper.

1. See Special Issue on Dispute Processing and Civil Litigation, 15 LAW \& SOC'Y REv. 395 (1980-81); D. Trubek, J. Grossman, W. Felstiner, H. Kritzer \& A. Sarat, Civil Litigation Research Report Project Final Report, Part A (Mar. 1983).

2. S. Goldman, Buying legal Services: A President's Guide (1976); M. Wessel, The Rule of Reason: A New Approach to Corporate Litigation (1976); Bernstein, Profit Pressures on the Big Law Firms, Fortune, Apr. 19, 1982, at 84; For Lawyers: An Inside Job, Bus. WK., Sept. 1, 1980, at 70; Gallucio, The Rise of the Company Lawyer, FORBES, Sept. 18, 1978, at 168; Reading the Riot Aat to Outside Counsel, Bus. WK., Feb. 22, 1982, at 39; R.S. Banks, Controlling Corporate Legal Cost, (address summarized in The Pace of Litigation: Conference Prockedings 21-23 (1982) (research supported by Institute for Civil Justice)). 
province of Quebec, which employs a civil law system) have common law legal systems and provide mechanisms for the review of legal fees. In both countries, the review mechanism is referred to as "taxation," which involves an examination of the bills by an officer of the court who is called the "taxing master" or the "taxing officer." The taxation mechanism came into existence as a way of reviewing claims for reimbursement for legal costs incurred by the victorious party during litigation which, as a result of fee shifting rules, were to be paid by the losing party. $^{3}$ Taxation can also be used to review legal fees incurred outside of litigation if a client is concerned that his or her solicitor is overcharging. ${ }^{4}$ My expectation was that the process of review would create expectations and norms regarding appropriate levels of effort and appropriate legal fees and that this set of norms, combined with the existence of the review mechanism, would serve to alleviate concerns regarding legal fees among larger business organizations. This, in turn, would result in an absence of the kind of changes taking place in the United States.

To investigate my hypothesis, I spent about four weeks in Toronto interviewing executives in major corporations headquartered there and partners in the major law firms who typically service the large corporations. ${ }^{5}$ In addition, I spoke with a number of persons working for smaller business firms, the court system, governmental agencies, corporations, and the business press. The particular persons to be interviewed were identified through a combination of personal contacts, referrals from other interviewees, and lists of major corporations and law firms. ${ }^{6}$ While I sought to talk to a range of people with a range of perspectives, the set of people I did speak with cannot be construed as a random sample of some clearly identifiable population. I conducted a total of sixty interviews; the interviews averaged about one hour in length.

Two things emerged from my interviews. First, I found no support for my original hypothesis. The nature of the relationships between large corporations and their outside lawyers is not affected in significant ways by the taxation process or by the norms that might be created by that process. In the words of several of my respondents:

\footnotetext{
"Taxation is more for the little guy."

"I never perceived the taxing officer as having an influence on bills; it is a factor that doesn't belong in a longstanding relationship between a client and his lawyer. It was considered bad form . . . to mention taxation."

"I wouldn't use the taxing officer. They're not a good thing for a corporation . . . . It can help a bit for the individual."
}

3. For a description of the process as it works in England, see Q. JOHNSTONE \& D. HOPSON, LAWiters and Their Work: An Analysis of the Legal. Profession in the Untred States and England 49699 (1967). For the specifics of the Ontario system, see REPORT OF THE ONTAR IO LAW REFORM COMMISSION ON Class ACTIONS 647 (1982) [hereinafter cited as ONTARIO LAW REFORM COMMISSION]; G. Watson, S. Borins \& N. Williams, Canadian Civil Procedures: Cases and Materials (1973).

4. Q. Johnstone \& D. Hopson, supra note 3, at 499.

5. For a general comparison of civil litigation in the United States and Canada, see C. Wanner \& C. McKie, Civil Court Caseload Dynamics in North America: A Comparison of Canada and the United States (presented at meetings of the American Political Science Ass'n, N.Y. Hilton Hotel, Sept. 3-6, 1981).

6. The Financial Post 500 (1982). 
"We've never considered taxing [our lawyer's bill] because we have an ongoing business relationship."

Second, since I was an American, my respondents were anxious to compare the situations in Canada and the United States. These comparisons tended to have several dimensions: general cultural differences, the effects of rules regarding costs, and the effects of rules prohibiting contingent fees. In the early interviews, it appeared that the absence of a contingent fee mechanism in Ontario was probably the biggest difference between the United States and Canadian practices; but as the interviews progressed, I realized that that conclusion was too simplistic and that the rules regarding fee shifting 7 probably played a more prominent part.

The balance of this article will offer an argument regarding the relative influence on legal practices of contingent fee mechanisms as opposed to fee shifting rules, and more importantly, will examine the relationship between the various rules and their effects, that is, who is affected by fee practices and under what kinds of circumstances the rules make an important difference. The first section will briefly describe the rules in Ontario regarding the computation of legal fees and fee shifting. It will then be argued that, with a proper understanding of what constitutes a "contingent fee," there are practices in Ontario that effectively amount to contingent fees, at least in some types of cases. Next, following presentation of a framework for understanding the impact of fee and cost systems, that framework will be used to analyze the impact of fee shifting rules in Canada. The conclusion will be a brief normative discussion of the implications of adopting fee shifting rules in the United States.

\section{Fees and Fee Shifting in Ontario}

The governing body of the legal profession in Ontario is the Law Society of Upper Canada. The Law Society, along with the courts and the provincial legislature, establishes the rules and regulations under which lawyers go about their work. One aspect of these rules involves the fees that lawyers may charge their clients. According to the rules, the fee in a matter involving litigation is not to be charged on a strictly hourly basis; rather, the fee is to take into account several factors including:

(a) the time and effort required and spent;

(b) the difficulty and importance of the matter;

(c) whether special skill or service has been required and provided;

(d) the amount involved or the value of the subject matter;

(e) the results obtained. ${ }^{8}$

Obviously, these rules leave a great deal of room for judgment-and for disagreement. ${ }^{9}$ The potential for disagreement is amplified by the fee shifting rules, which permit a successful litigant to recover from the opposing party a portion of the fees

7. Note that I am concerned here only with two-way fee shifting.

8. Law Soc'y of Upper Canada, Professional Conduct Handbook 24 (1978); see also G. WATSON, S. BORINS \& N. Williams, supra note 3.

9. My interviews suggest that the corporate community is becoming more resistant to accepting what 
paid to his or her lawyer. Obviously, the losing party is going to want to minimize the amount to be paid for the opponent's lawyer's fees.

The process of taxation is the mechanism for determining the amount to be paid in legal fees. If an amount cannot be agreed upon by the parties involved, the taxing officer, who is a court official, reviews the account submitted by the lawyer and then makes a judgment, based upon a set of tariffs and his knowledge of the practice of law, as to whether the fee charged is appropriate. If the taxing officer views the fee as excessive, he is empowered to reduce it by adjusting the rate charged or by disallowing charges for specific activities. The activities allowed and rate permitted will depend on the nature of the taxation. ${ }^{10}$

There are two basic types of taxation, one dealing with partial indemnification for legal expenses in litigation and the other dealing with what a client should pay his or her own lawyer. The first type is referred to as taxation on a "party and party" basis and the second as taxation on a "solicitor and client" basis." Typically, in litigation, a successful litigant is awarded "party and party" costs to be paid by the other side. 12 "Party and party" costs are only a partial reimbursement ${ }^{13}$ for a litigant's legal fees; the litigant is then responsible for the balance of his or her lawyer's fee. If a client feels that his or her own solicitor's fee is excessive, the client may take the lawyer before the taxing officer to have the bill reviewed; ${ }^{14}$ taxations of this sort are done on a "solicitor and client" basis.

In some situations, a succesful litigant may be awarded "solicitor and client" costs - that is, a higher percentage of actual costs than is usually awarded on a "party and party" basis-from the other side. Such an award is generally made when the judge believes that the losing side acted irresponsibly in pressing its claim or defense. Some of my respondents further distinguished between a "solicitor and client" and a "solicitor and own client" award from a losing party with the former involving recovery of $80-90 \%$ of reasonable litigation expenses and the latter involving a $100 \%$ recovery. ${ }^{15}$

An additional element of the fee shifting rules in Ontario is the mechanism of "paying into court" whereby a defendant who has conceded liability but who has been unable to reach an agreement with the plaintiff regarding the amount of

might be described as a "fuzzy" system for bill calculations; one of the lawyers I spoke to described the traditional method of setting of accounts as an "art" rather than as a mechanical calculation.

10. See Q. Johnstone \& D. Hopson, supra note 3; M. Orkin, The Law of Costs (1968); G. WATSON, S. BORINS \& N. WILliAMS, supra note 3.

11. See Law Soc'y of UpPer Canada, Costs: Party and Party Updated (1978); Law Soc'y or Upper Canada, Proceedings of the Programme: Solicitor and Client Costs (1971). The terminology "party and party" and "solicitor and client" may be a bit confusing. Both terms might be clarified by preceding them with "between": "between party and party" (that is, from one party to the other) and "between solicitor and client."

12. A recent study of reported cases suggests that judges deviate from the "party and party" norm in a substantial fraction of cases. See Lantz, Costs as a Regulatory Device, 2 Advocates Q. 396 (1981).

13. The reimbursement is typically somewhere around $50 \%$, although subjects interviewed cited figures ranging from $30-70 \%$.

14. A solicitor can also take a client to taxation as a means of enforcing collection of a bill.

15. At least one of my respondents, however, expressed a strong opinion that, while the courts referred to "solicitor and own client" costs, the difference between such an award and a mere "solicitor and client" recovery has never been spelled out by the courts. See also Lantz, supra note 12, at 403; ONTARIO LAW REFORM COMMISSION, supra note 3 , at 650 . 
damages can place the plaintiff at risk for a portion of the defendant's costs. This is done by making a formal offer of settlement by paying the amount of the offer to the court; if the plaintiff refuses the offer and then fails to obtain a better judgment at trial, the plaintiff becomes responsible for the defendant's "party and party" costs from the date of the formal offer. ${ }^{16}$

One of the problems with payment into court is that it is onesided. It can be used to force the plaintiff's hand, but there is no parallel mechanism by which the plaintiff can shift the incentives to encourage the defendant to agree to the amount of damages to be paid. To deal with this asymmetry, a proposal has been made in Ontario to replace payment into court with a system of "offers of settlement."17 Under this new procedure, either side could make an offer of settlement at any time after the case was filed. If the offer were made by the defendant, the mechanism would work essentially the same way as payment into court, with the plaintiff then being at risk for a portion of the defendant's "party and party" costs. If the offer were made by the plaintiff (who, if successful, is now entitled to "party and party" costs unless he or she fails to better the defendant's offer) and the defendant rejected the offer and the plaintiff were awarded that amount or more at trial, the defendant would become responsible as well for the plaintiff's "solicitor and client" costs from the date of the offer.

III

\section{Contingent Fees in Ontario}

One of the ways interviews with Toronto respondents frequently began was by describing the difference between the "litigation problem" in the United States and Canada:

"If there were a contingent fee in Canada, lawsuits would increase by 50\%."

"We are currently involved in more litigation in the U.S. than in Canada even though our major operations are in Canada."

"Canadians seem to be a lot less litigious than Americans."

"There's a lot less [litigation in Canada] because of no contingent fee . . . the contingent fee in the U.S. makes people more litigious."

Thus, the clear perception of my respondents was that the litigation rate in Canada is much lower than in the United States, though none could cite any general statistics. ${ }^{18}$ Canadians tend to attribute this differential, at least in part, to their lack of contingent fees. ${ }^{19}$ There are problems, however, with this conclusion.

16. G. WATSON, S. BORINS \& N. Williams, supra note 3, at 2-37.

17. Draft Rule 49, Report of the Civil Procedure Review Committee 159 (1980).

18. A recent publication compared the litigiousness of Americans to that of citizens of a number of Western countries; however, the publication's author was unable to locate any data that would permit an estimate of the litigiousness of Canadians. M. Galanter, Reading the Landscape of Disputes: What We Know and Don't Know (and Think We Know) About Our Allegedly Contentious and Litigious Society, 31 U.C.L.A. L. REv. 4 (1983). If one is willing to accept the argument that Australia and Ontario should produce roughly comparable trends (the major significant system difference is that Australia has a divided legal professionbarristers to handle courtroom work and solicitors to provide general legal counseling), then a recent Australian study should bolster the argument that Canadians are less litigious than Americans. See J. FitzGerald, A Comparative Empirical Study of Potential Disputes in Australia and the United States (1982) (Disputes Processing Research Program Working Paper 1982-4, Univ. of Wis.-Madison).

19. In Ontario, contingent fees are deemed to be unethical unless explicitly permitted by law: 
This is not necessarily to say that the absence of contingent fees has no effect, but rather that the contingent fee may not be as absent as many people think, and that its presence or absence may not have as much of an effect as is commonly believed.

First, all of the Canadian provinces except Ontario do in fact permit contingent fees, ${ }^{20}$ and none of my respondents, many of whom are executives in corporations with major operations in provinces where contingent fees are permitted, made any mention of a greater litigiousness among the residents of the areas with contingent fees. This result seems to represent a major inconsistency in the argument that a substantial portion of the difference in litigiousness can be attributed to the presence or absence of contingent fees.

Second, and perhaps more important, is the point that "contingent fees," with a proper understanding of what the term means, may, for all practical purposes, exist in Ontario. One image of a contingent fee system is a simple "no win, no pay" provision overlaid on some specific method of calculating fees such as a flat amount or an hourly rate (or a method like that in Ontario where the fee takes into account the time, the amount in controversy, the level of expertise required, and the result achieved). ${ }^{21}$ This is not the way contingent fees work in the United States or in the Canadian provinces that permit such fees. ${ }^{22}$ The American system would be better described as a "percentage fee" system in which the lawyer receives a percentage of the recovery (which by definition means that if the recovery is zero dollars, the lawyer receives zero dollars). ${ }^{23}$ One would be hard pressed in the United States to find a lawyer who would accept a contingency arrangement for an hourly fee calculation. Is then the key difference between the United States and Ontario the fact that American lawyers will accept fees on a percentage basis while Ontario lawyers are not permitted to accept such arrangements?

Further interviewing, however, revealed that there is in fact a set of practices among many lawyers in Ontario that creates a system of fees that functions much like the American percentage fee system. In the words of several of my respondents:

"The successful plaintiff's lawyer usually charges $10-15 \%$ of the recovery, plus the ['party

A lawyer should not, except as by law expressly sanctioned, acquire by purchase or otherwise any interest in the subject matter of litigation being conducted by him. It is improper for him to enter into an arrangement with his client for a contingent fee except in accordance with the provisions of the Solicitors Act.

LAW SOC'Y OF UPPER CANAda, supra note 8, at 26.

20. Manitoba has, by statute, permitted contingent fees since 1890. Minish, The Contingent Fee Reexaminae, 10 MAN. L.J. 65, 69 (1979). Today contingent fees are permitted by statute in Alberta, British Columbia, Manitoba, New Brunswick, the Northwest Territories, Nova Scotia, and Quebec. LAw Soc'Y OF UPPER CANADA, supra note 8, at 66. In Saskatchewan, contingent fees have been permitted as a result of court rulings. E.g., Speers v. Hagemeister, 52 D.L.R.3d 109 (1975); see J. Swartz, Lawyer Contingent Fee Agreements in Canada (Sept. 1975, updated Apr. 1976) (unpublished memo) (available in AmericanBritish Law Division, Law Library, Library of Congress).

21. See supra text accompanying note 8 .

22. One key difference between contingent fee agreements in the United States and the various Canadian provinces that permit them is that in Canada those agreements, and the fees themselves, are subject to review by the courts and/or the taxing officers. See G. WATSON, S. BORINS \& N. WILliams, supra note 3 , at $2 \cdot 53$.

23. Cf. Grady, Some Ethical Questions about Percentage Fees, 2 Litigation 20 (1976). 
and party'] costs recovered from the defendant. . . I would bill an unsuccessful client, but I probably would not take the client to taxation [to try to force him to pay the bill] if he couldn't pay."

"[n some, but not many, cases] the lawyer is taking the case on the basis that there will be some recovery and his fee would be a percentage."

"Personal injury firms exist who, if they do not win, do not expect to be paid."

An additional quotation provides a good hint of the fields in which the abovementioned kinds of practice which are most likely to occur:

"In effect we have [a percentage fee system] here, at least in personal injury cases."

In a sense, this may simply reflect the methods of large insurance companies who find some simple percentage system the easiest way to calculate how much they will pay in "party and party" costs:

"In a personal injury case, the insurance company will [usually] pay $15 \%$ of settlement amount as ['party and party'] costs [to the plaintiff's lawyer]."

There is far from unanimous agreement that such practices are to be found in Ontario; many lawyers, particularly those in smaller firms that do personal injury plaintiff's work, denied that such practices exist. Many of the lawyers, however, who rejected the analysis that there was effectively a contingent fee system would immediately say things such as:

"Where the client has a good case, he can find a lawyer."

"I send interim bills for litigious matters except for personal injury cases and matrimonial matters."

Such comments tend to lead one to believe that practices resembling those described earlier are quite common, at least in the kinds of cases where lawyers are quite confident that some recovery will be made. ${ }^{24}$ This is really no different than the American system, since few lawyers will accept marginal cases on a contingent fee basis unless there is a chance of a very large recovery. Moreover, no respondents interviewed would deny that there was a $15 \%$ rule of thumb for "party and party" costs in insurance cases, though there was substantial disagreement about how much over and above the "party and party" costs a lawyer would charge. The "surcharge" mentioned ranged from 10-15\% of the underlying recovery (for a total fee of $25-30 \%$ of the recovery, which sounds strikingly like the percentages usually charged by plaintiff's lawyers in the United States) to as low as 20-30\% of the "party and party" costs obtained. One lawyer indicated that he does not send a bill to his client until after taxation and that then "the bill will be minimum of $130 \%$ of what is taxed." It should be noted that while the rules regarding fee setting say nothing about percentage fees and there seems to be agreement that it would be unethical to have a formal percentage fee agreement with a client, the previously listed ${ }^{25}$ factors to be considered-specifically the amount in controversy and the result achieved-are not inconsistent with a substantial percentage ele-

24. There would also appear to be some support in the Rules of Professional Conduct for a practice of not pursuing payment with an unsuccessful client: "It is in keeping with the best traditions of the legal profession to reduce or waive a fee in a situation where there is hardship or poverty . . . ." LAw SOC'Y OF UPPER CANADA, supra note 8, at 24.

25. See supra text accompanying note 8 . 
ment in the calculation. ${ }^{26}$

I suspect that few lawyers in Ontario ever explicitly indicate to their prospective clients that the fee will be figured on a percentage basis. At the same time, I would expect that a common reply to the inevitable question "What is this going to cost me?" goes something like the following:

I can't tell you exactly what this is going to cost. But you know that if we are successful, the other side will have to pay a substantial proportion of my fee. I expect that in the end the cost to you will be about 10 or $15 \%$ of whatever we manage to recover, and you have a very good case so I expect we will be able to get a good settlement.

A client who has heard a statement of this sort is likely to be fairly content when, after the case is concluded, he or she receives the lawyer's bill and finds that the amount owed is around 15\% of the settlement (after all 15\% is a fairly small fraction-it certainly looks much smaller than the $30 \%$ or so that an American lawyer takes off the top.) ${ }^{27}$

Let us presume that few people who have good cases are unable to obtain lawyers because they are unable to pay the fees that the lawyers will demand. Then, excluding cultural differences, there are two explanations for a lower propensity to sue in Canada. First, substantial numbers of persons may simply not realize that there are lawyers who will take their cases without demanding substantial fees "up front." (But why then was there not a perception of more of a litigation problem in those provinces which permitted contingent fees? ${ }^{28}$ ) Alternatively, there may be other types of barriers to litigation, such as the possibility of having to pay the other side's costs if one loses. If one assumes that individuals tend to be risk averse, then a fear of having to pay the other side's costs, even if one is not concerned about one's own costs, may be a substantial deterrent to litiga-

26. Compare this to the following statement in G. WATSON, S. BORINS \& N. Williams, supra note 3 , at 2-52:

However it is a common practice in Ontario in personal injury litigation for a solicitor to undertake an action on behalf of a plaintiff on the understanding that the solicitor will not ask for a fee, or that he will ask for only a minimal fee, if the action should fail and will ask for his usual fee if the action should succeed.

See also ONTARio LaW Reform COMmission, supra note 3, at 655.

27. It is impossible to determine how widespread practices of this sort are. Respondents mentioned percentage fees as probably existing in areas other than personal injury when the litigation involves individuals and the primary dispute is over the amount of damages rather than over liability; for example, in wrongful dismissal cases (an area that is relatively new in the United States) and in human relations cases (what we call civil rights). The amount of corroborating evidence for the argument that percentage fees are widespread is minute. Consider, however, the description of a highly successful plaintiff's at torney in a recent book on Canadian lawyers. The passage included fairly detailed discussions of three cases he had handled, and in two of those discussions the fees and recoveries that were mentioned indicated that the client had received $75-80 \%$ of the amount recovered. By presumption, the remainder of the recoveries went to the lawyer. J. BATTEN, LAWYERS 23, 30 (1980). See also a case described in G. WATSON, S. BORINS \& N. Williams, supra note 3 , at $2-59$, in which a personal injury plaintiff obtained a settlement of $\$ 40,000$ plus $\$ 6,000$ in "party and party" costs -exactly $15 \%$. The taxing officer questioned whether the solicitor's effort warranted such a fee, to say nothing of the additional $\$ 5,000$ that the solicitor sought to add to the $\$ 6,000$ received from the defendant for a total fee of $\$ 11,000$, or $27.5 \%$ of the recovery.

28. See supra text accompanying note 20. Also, Nova Scotia only recently (in the mid-1970's) adopted rules permitting contingent fees, yet conversations I had with barristers in Halifax do not suggest that this change has resulted in a sudden increase in cases (unfortunately, the kind of data that would permit a statistical test of this observation is not available). Most likely this simply means that other practices, such as that described supra in note 24 , served as informal contingency arrangements. 
tion. ${ }^{29}$ No doubt both of these explanations contain elements of truth. However, for those with an interest in fee shifting rules as a possible way of changing the legal system, the implications of this analysis are clear: The potential of having to pay the other side's costs may create a very substantial barrier to litigation, particularly for individuals and especially when the potential litigant is not $100 \%$ sure about his or her case.

\section{IV}

\section{A Framework for LoOking at the Impact of Fee Reforms}

To accurately understand the impact of fee and cost reforms on litigation, one must look at the various segments of the world of litigation. The interviews in Toronto plus previous research on civil litigation point toward two relevant dimensions: the nature of the cases and the nature of the litigants. One of the major findings of CLRP was that most civil cases in our courts of general jurisdiction involve relatively modest claims. While some of the recent literature on civil litigation ${ }^{30}$ and much of the discussion of civil justice reform seems to see the world of litigation as involving many substantial cases $(\$ 50,000$ and above) with significant amounts of pretrial activity (such as motions and discovery), the CLRP analysis indicates very clearly that only a small fraction of state cases involve more than $\$ 50,000$ and only a slightly larger fraction of federal cases involve that amount and that most cases are handled in a fairly routine and straightforward way. ${ }^{31}$ This suggests that in thinking about the impact of fee and costs reform, we should divide the litigation into the "ordinary or routine" cases and the "substantial or nonroutine" cases.

Indeed, the Toronto interview respondents repeatedly had to distinguish between large and small or routine and nonroutine cases in order to discuss the impact of fee shifting: ${ }^{32}$

"The smaller the case, the more important costs become."

"[I don't] think fee shifting has any effect on major litigation . . . you can only get a 'flea bite' of your costs. . . . [It's] more important in small cases."

"Fee shifting doesn't affect us at all in a [significant] case but regarding small matters . . . oh, yes...."

The second factor that needs to be considered in evaluating fee shifting proposals is the nature of the litigant. The differing impact of cost rules on individuals and business corporations was also frequently mentioned by interview respondents:

"Fee shifting is very significant for individuals . . . for corporations, costs and fee shifting is just another factor in the calculation."

29. The common wisdom seems to be that individuals are risk averse while organizations are risk neutral; see T. Rowe, Attorney Fee Arrangements and Dispute Resolution 28 (updated Feb. 23, 1983).

30. See, e.g., Brazil, The Adversary Character of Civil Discovery: A Critique and Proposals for Change, 31 VAND. L. REv. 1295, 1310 (1978); Brazil, Views from the Front Lines: Observations by Chicago Lawyers about the System of Civil Discovery, 1980 Am. B. Found. Research J. 219, 220 (1980).

31. D. Trubek, A. Sarat, W. Felstiner, H. Kritzer \& J. Grossman, The Costs of Ordinary Litigation, 31 UCLA L. REV. 72 (1983).

32. In part, this dichotomy betwen big and small cases simply reflects the cost of legal services to corporations: "For litigation the meter starts at $\$ 10,000$ and quickly runs up to $\$ 50,000$." 
"It can spell financial ruin for an individual to get involved in litigation and lose; for corporations, it's a business expense."

This dichotomy between businesses and individuals reflects a combination of the repeat-player versus one-shotter distinction of Marc Galanter ${ }^{33}$ plus the difference between the relationship of an individual to his or her money and the relationship of a business entity to its money. In a sense it's a matter of scale, and in a sense it's a matter of risk preference; these two phenomena are not unrelated.

The two dimensions, size of case and type of litigant, may be combined to produce a fourfold table: ${ }^{34}$

TABLE 1

TYPE OF LITIGANT

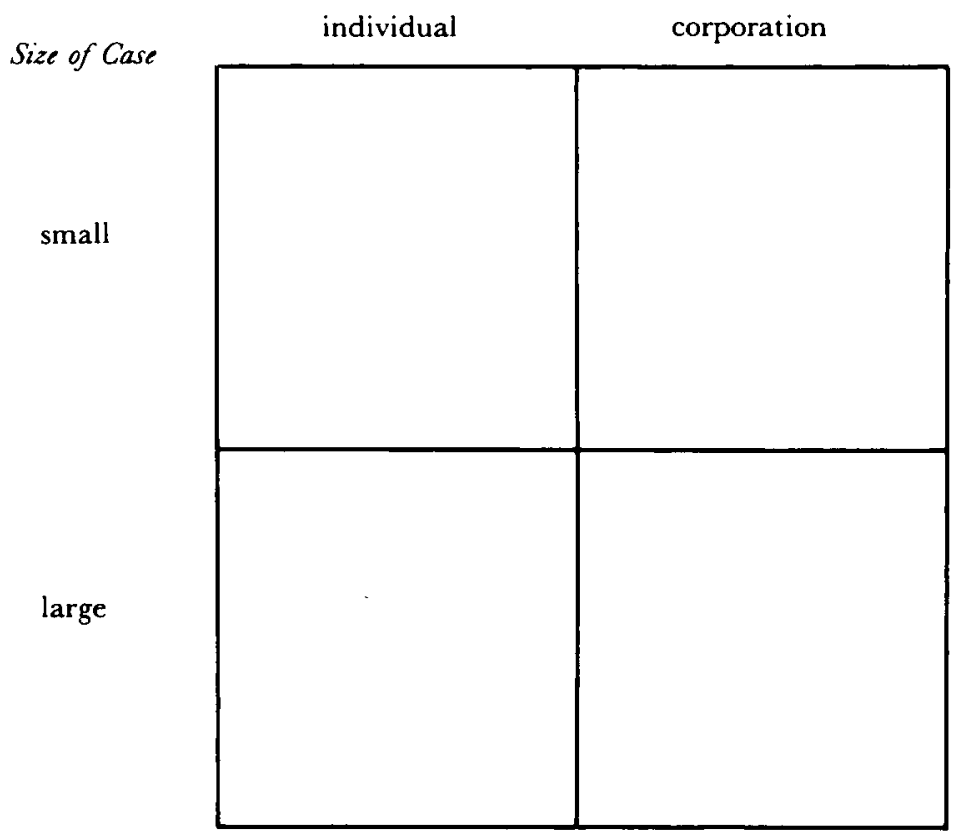

The impact of fee shifting would seem likely to depend upon which of the four cells one is thinking about.

\section{$\mathrm{V}$ \\ The IMPaCt OF Fee Shifting}

Looking first at the impact of fee shifting upon a business corporation involved in a significant case, the costs of litigation, at the simplest level are simply one aspect of the cost of doing business. Decisionmaking in most cases is best under-

33. Galanter, Why the "Haves" Come Out Ahead: Speculations on the Limits of Legal Change, 9 LAw \& SoC'Y REv. 95, 97 (1974); see also Rowe, supra note 29, at 15.

34. It is important to note that while the two dimensions are presented in the form of dichotomies, in fact the variables defining both dimensions are better thought of as continuous variables. 
stood in terms of business considerations. In a very significant case, if the suit involves a major threat to the company or the way it operates, costs and fee shifting are not likely to have much impact on the course of a case:

"In big cases legal costs are a minor factor given what's at stake. . . It doesn't matter what the cost system is."

Furthermore, in significant cases where all of the major parties are organizations, each side usually bears its own costs if the case is settled prior to trial.

In relatively large cases (over $\$ 50,000$ ) where the issue is simply one of money rather than a threat to the company's operations, costs and fee shifting are just parts of the economic calculation involved in trying to settle a case:

"It's just another factor to calculate in settlement negotiations."

"Fee shifting has an effect on what you do, particularly vis-a-vis settlement where the emphasis is on the bottom line."

"You have to think about [the] net in setting [a] bargaining figure."

"Essentially [it is] another add-on in the general cost benefit calculation in deciding how to proceed."

"Fee shifting does affect [the] decision whether or not to fight a case, but [it is] just another factor in the monetary calculation."

Fee shifting and costs in such instances affect not only evaluations of the "bottom line" but the timing of settlements as well:

"It is often a major consideration in prompting 'courthouse steps' settlement."

"In many cases, cost factors [including fee shifting] are decisive in whether you settle, go to trial, or even initiate a matter."

The quotes above suggest the broader impact of fee shifting: As the case gets smaller and smaller, the potential impact of fees on the calculation increases.

But even in the context of smaller cases, fee shifting is simply a part of the economic calculation involved in a business decision:

"If the case is weaker than it might be, I might be more likely to settle because . . . opposing party's costs are another factor in the calculation."

"Fee shifting forces people to be more realistic about what they want to accomplish."

The net effect of these economic calculations is to encourage settlement of cases, ${ }^{35}$ particularly when the corporation is a defendant, or to discourage the initiation of lawsuits when the corporation is a plaintiff, particularly if there are doubts about the case:

"I'm aware of fee shifting and that plays a role in determining if settlement is possible."

"The cost system discourages frivolous litigation . . . people think out the quality of a case before proceeding."

"Fee shifting is one of the deterrents to pursuing a losing case."

"Fee shifting makes people with doubtful cases a bit cautious before proceeding."

"Costs have a calming effect."

"Rules of costs have an effect on starting a lawsuit and [on] decisions on how far to take [a] case."

"The possibility of having to pay the other side's costs does affect the decision to proceed."

"Costs have a greater role in whether you engage in litigation [in a fee shifting system] because if you lose the costs include both your own side's and [a portion of] the other side's."

35. Another economic factor that was mentioned as affecting settlement was the practice of making interest awards at up to the prime rate from the date of the writ or even the date of injury. This practice, which started in 1975, was described as having "a profound effect on litigation." 
What is striking about this set of quotations is the thread of linkage between the quality of a party's case and the impact of concern about losing. What is unstated above (it was only mentioned by two respondents) is the possibility that fee shifting might encourage litigation or the pursuit of a case if the party believed that the probability of winning was high. ${ }^{36}$ This simply reflects the fact that, under fee shifting arrangements, a successful litigant does not have to bear all of his or her costs; and if a litigant were confident of winning, fee shifting might encourage pursuit of a smaller case which it otherwise would not be economical to litigate: ${ }^{37}$

"Plaintiffs who feel they have a good case will push on in the expectation of recovery of a portion of their costs."

In regard to individuals, however, the virtually unanimous conclusion of the interview respondents who spoke to the question was that fee shifting serves to discourage persons from pursuing cases they otherwise might litigate or to encourage them to accept settlements that are smaller than they might be able to get at trial:

"The system of costs has a deterrent effect for individuals . . this in turn encourages settlement."

"The risk of losing tends to make people nonlitigious ... the chance of having to pay a substantial chunk of costs has an inhibiting effect."

"The potential of costs against deters many small litigants."

"The system is double-edged . . . it is destructive of the right of the middle class to get its day in court."

"The burden of costs on the loser tends to drive parties out of court."

"Clients don't get justice because they can't afford it."

One view of all of these quotations is that they perceive the individual as a plaintiff who would be initiating a lawsuit. What about the individual as a defendant? It does not appear that fee shifting increases the likelihood that a corporation will sue an individual; this reflects the fact that it does one no good to receive an award for costs if the other side cannot pay the award:

"We have made it a policy not to sue a person until we've gotten a financial report on him."

This same concern about being able to collect costs if awarded seemingly offsets what might have been the expected incentive for an individual defendant to resist settlement if there were a substantial likelihood of winning the case. One former defendant's lawyer (now a government litigator) said:

"In private practice, I was very concerned about costs, particularly in relationship to what was at stake, and [whether] the plaintiff would be able to pay the costs [if we won]."

Another defendant's lawyer indicated that the problem of collecting a cost award from an unsuccessful plaintiff served to

"encourage the defendant to settle because he can't recover costs even if he wins."

This lawyer said that the problem comes up so often that he

"would like to have procedures to move for security for costs."

36. Encouragement of litigation would clearly be the impact of one-way fee shifting rules.

37. See Rowe, The Legal Theory of Attomey Fee Shifing: A Critical Overvieie, 1982 DukE L.J. 651,665 (1982). 
The point raised in the last paragraph suggests that fee shifting, in the case of individuals involved in major litigation, may have less influence on a person's willingness to become engaged in such if the threat of costs against does not have any real teeth. Of course, if the individual has a significant asset, such as a house, which could be seized to pay a large costs against award, the threat of costs against will have a significant deterrent effect. Similarly, if there were general procedures for requiring a plaintiff to post security for the defendant's potential costs, fee shifting might have more effect. ${ }^{38}$ Uther aspects of the Canadian system, such as the difficulty of pursuing class action suits and the unwillingness of lawyers to take significant cases without interim payment of legal fees, have greater inhibiting effects on litigation by individuals than does fee shifting. Similarly, the absence of an accepted contingent fee has a clear inhibiting effect in the frontier areas of the law. In a percentage fee system, lawyers can be found who will undertake what might be described as "speculative" litigation; this practice does not appear to be the case in Ontario. The absence of a large segment of the populace from major litigation was explained very succinctly by two of my respondents:

"Only corporations and the indigent can afford major litigation."

"Litigation is a sport of the very rich or very poor."

\section{VI}

\section{Conclusions}

It seems clear from the above discussion that the overall effect of fee shifting is to inhibit the initiation and pursuit of legal actions. The basic question that must ultimately be answered is whether this is good or bad. If one believes that there are a substantial number of what amounts to frivolous lawsuits in which a plaintiff obtains a settlement simply because of the defendant's concern about the costs of fighting the case, then fee shifting would probably serve to discourage suits of that type. There is certainly an argument to be made that if a person or organization is sued unjustly, then that party should have the right to recover the costs incurred in defending the case; in the words of a corporate official in Toronto:

"It just offends you to be able to have someone sue you and lose, and not recover anything for your costs."

Yet, while one could make the argument that fee shifing would discourage the relatively small "nuisance" suit, the mechanism may not be of much help to prevailing defendants in significant cases. The realities of the costs of litigation would probably preclude recovering more than a small portion of one's defense expenses from an unsuccessful plaintiff (assuming that the plaintiff was an individual).

The opposite side of the question is whether fee shifting rules would serve to discourage a substantial number of persons who had valid grievances but were concerned that they might not be able to win in a court of law, thus suffering their own damages and also having to pay the other side's costs. The impressionistic

38. In Ontario, security for costs can be required in certain circumstances, such as when the plaintiff is a nonresident or when the government is the defendant. See G. WATSON, S. Borins \& N. Williams, supra note 3, at 2-38; see also OnTARio Rules of Practice 373. 
evidence obtained from this set of sixty interviews points clearly to the deterrent effect of fee shifting. Many cases that are filed in the absence of fee shifting would not be filed if the strong potential for fee shifting did exist.

In the end, the question comes down to the problem of finding a balance between permitting aggrieved parties to have easy access to the courts and deterring parties from "oversuing" when their cases are marginal or nonexistent. There is probably no "empirically correct" answer to this dilemma. It becomes a question of which is the greater injustice: the injustice of being unfairly sued or the injustice of not being able to recover damages for an injury? Given the fact that most lawsuits in the United States (excluding simple debt collection and divorce suits) involve organizations as defendants and either individuals or organizations as plaintiffs, ${ }^{39}$ the question of which type of injustice should be borne comes down to the question of who should bear injustice, individuals or organizations? There is a normative or political argument to be made that it is better for society to place the burden of injustice on organizations because the impact of such injustice is more limited and diffused than if the injustice were to be borne largely by individuals. Most important, this argument tends to suggest that while the costs of injustice are both monetary and nonmonetary, the organization, in contrast to the individual, is not particularly sensitive to the nonmonetary costs, and the organization can better bear the overall costs.

39. Grossman, Kritzer, Bumiller, Sarat, McDougal \& Miller, Dimensions of Institutional Participation: Who Uses the Courts and How, 44 J. POL. 86, 102 (1982). 